\title{
Costing of Oil and Gas Projects for Efficient Management and Sustainability
}

\author{
Dr. Uchenna .O. Ajator \\ Department of Quantity Surveying, Nnamdi Azikiwe University,Awka-Nigeria
}

\begin{abstract}
Oil and gas plant is a chaotic web of equipment, piping, buildings e.t.c. The costing of this plant means costing of the processing machines, equipment, pipes etc and other electro-mechanical components including buildings and civil works infrastructure which form the basis of procurement and management of the fluid process. This study reviews the basic considerations, activities and appropriate steps for estimating oil and gas projects. It identified the aloofness of the oil industry and inadequate cost management practices for the sector which controls the commanding height of the Nigerian economy. It recommends among others that Quantity surveyors as the country's construction cost 'watchdog' should in liaison with other professionals exercise effective cost management of process projects as is done by cost engineers abroad to ensure sustainable growth of the Nigerian economy.
\end{abstract}

Keywords: Cost Estimate, cost management, sustainability.

\section{Introduction}

Nigeria is blessed with abundant oil and gas. The country is struggling to develop the technology, expertise, finance and other resources required to optimally realize the macro-economic development benefits of the activities of oil and gas which at the moment has foreign dominance. [1] report opined that the oil and gas sector in Nigeria is more of an external sector because it appears to have a disconnect with other sectors of the economy. Part of NEEDS assessed strategy for improving the oil sector include to increase local content, create linkage with other sectors of the economy, unbundle the Nigerian National Petroleum Corporation (NNPC) through privatizing its downstream subsidiaries and enabling Nigerian Petroleum Development Company and NNPC to compete as other oil companies around the world. The oil and gas industry is very significant to Nigerian economy as earnings from this sector constitute the principal source of revenue and foreign exchange used for financing Government expenditure, despite concerted efforts to diversify the country's economic base. As the nation's professional cost advisers and managers it becomes imperative for the quantity surveyor to extend it's costing, monitoring and cost control services to the oil sector to add value to the Nigerian economy. This is because an industry that provides over $70 \%$ of budgeted expenditure must be efficient at all times to ensure steady economic growth.

Costing of oil and gas projects present great opportunities for the Quantity Surveying consultants as is the case in advanced countries where cost engineers perform this role.

Aside from cost estimate and cost plan, cost control and management is a critical competence of the quantity Surveyor, to ensure that the integrity of planned project cost are sustained within the continuum of project delivery amidst several construction risks that tends to steer projects towards cost overrun [2].

Studies (undated) show no clear evidence of implementing good cost planning and control processes in the Nigeria oil and gas sector. But what abounds is tremendous empirical evidence on cost overruns in Nigeria development projects.

High cost of construction has remained the most cited single factor that militates against massive infrastructure development in Nigeria. This truncates efforts by Government, and other stakeholders in providing critical infrastructure necessary for socio-economic enhancement of Nigerian citizens. Thus accurate cost prediction, control and management at all stages of projects development pose great challenges to the quantity surveyor as the nation's construction cost watchdog [3, 4, and 5].

Estimating cost of process projects are done using techniques ranging from conceptual (approximate, stochastic) methods to deterministic (detailed or definitive) methods.

The quality/accuracy of the cost estimate and its management determine whether the project will succeed or fail. And the accuracy of the estimate depends among other factors on the estimator's knowledge and skill and quality/integrity of information (database) upon which the estimate was based.

The intent of this treatise is to expose the standard techniques of estimating costs of process plant projects of which oil and gas is one. To showcase the extension of the cost data to measure cost performance during project construction stage to ensure efficient management and finally to apply the cost data to develop lifecycle costing and management that would ensure sustainability of the process plant and recommend other social and community related issues that must be applied to support sustainability of operational plant. 


\section{Literature}

Process Engineering plants generally convert some form of natural or synthetic material into finished good for direct consumption of industries and the public.

Petroleum refining begins with the distillation, or fractionation of crude oils into separate hydrocarbon groups. The resultant products are directly related to the characteristics of the crude processed.

Most distillation products are further converted into more usable products by changing the size and structure of the hydrocarbon molecules through cracking, reforming and other conversion processes. These converted products are then subjected to various treatment and separation processes such as extraction, hydrotreating, and sweetening to remove undesirable constituents and improve product quality. Integrated refineries incorporate fractionation, conversion, treatment, and blending operations and may also include petro chemical processing.

Equipment, facilities and structures are integrated to carryout this conversion which may include a combination of mechanical, electrical and chemical operations.

Other Refinery operation's facilities which also have auxiliary facilities include: -Heat exchangers, coolers and process heaters. Steam generators.

Pressure Relief and flare systems $*$ waste water treatment $*$ Cooling towers

* Electric Power * Gas and air compressors * Marine, Tank Car and Tank Truck loading and unloading * Turbines * Pumps * Piping and valves * Tank storage * and health and safety facilities applicable to the various operation [6]. An important feature of this industry is the integration of engineering design installations.

Industrial engineering is the aspect of factory management concerned with the design of management process which takes into consideration, the improvement and installation of the integrated system of men, materials and equipment towards achieving the desired goals or output of goods and services $[3,7]$.

Hence costing of process/industrial installations means costing of the processing machines and/or equipments and all the associated electro-mechanical components which form the basis of procurement and management of most industrial projects e.g. refineries, large power stations large manufacturing and processing factories etc. including the costing of building and civil works infrastructure that constitute significant part of the project cost.

Chemical plant is a chaotic web of equipment, piping, buildings etc. Aside from the installed machinery and its allied components the factory would also have some or all of the following buildings and civil works infrastructure and possibly more:-

- Buildings to shelter the installed machinery and other components, unless it is an outdoor type of plant.

- Building for storage of raw materials and finished goods.

- Administrative buildings, staff residences.

- Civil works infrastructure such as roads, drainages.

- Power supply, water supply

- Storage and distribution and Telecommunications facilities.

- Support services or utilities (eg fire fighting, industrial health and safety and security with all associated building and civil works).

- Environmental management facilities such as waste disposal facilities, pollution control etc.

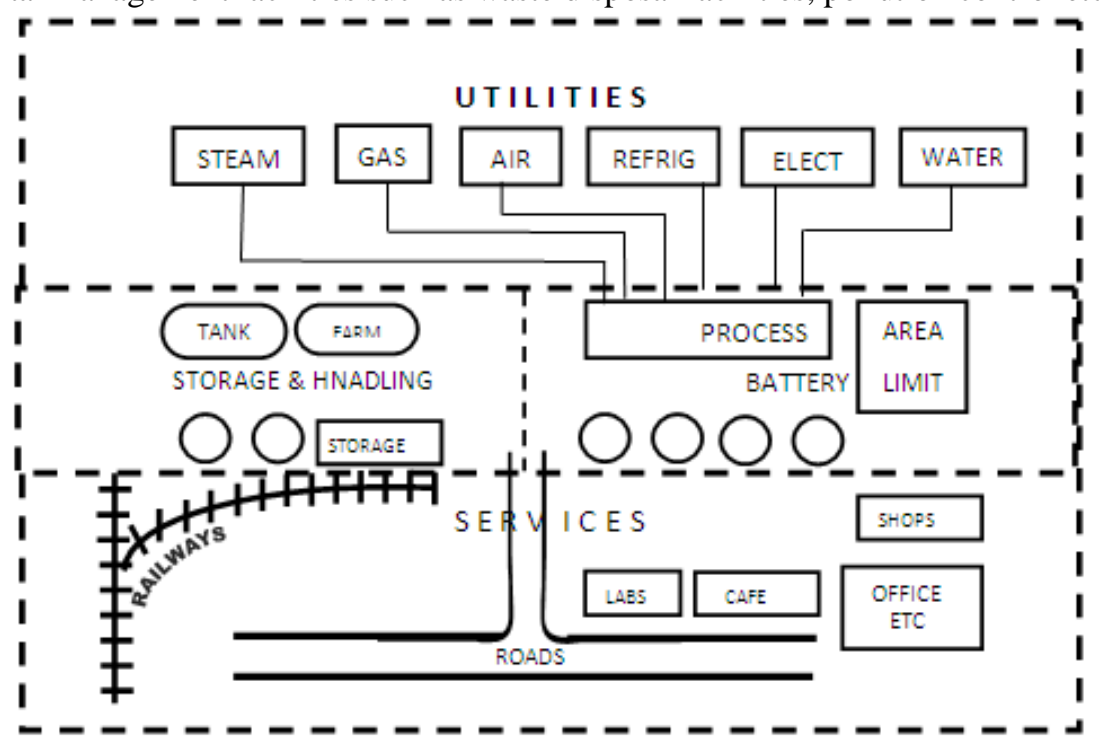

Figure 1: four area concept of process plant 
All chemical plants have four main areas (see Fig. I)

- Process Area or Battery Limit. Inside (ISBL)

- Storage and handling facilities for raw materials and finished products.

- Utilities such as steam, gas, air, refrigeration, electric, water, sewers/effluent treatment systems etc.

- Services such as labs, café, offices, shops, roads rails etc.

The storage, utilities and services areas constitute outside Battery limit.

Heavy engineering capital projects measurable under civil engineering standard method of measurement CESMM3 or the standard method of measurement of industrial engineering construction SMMIEC or equivalent building and engineering standard method of measurement BESMM3, possess features that make the type of detailed measurements in buildings unnecessary or unrealizable. These measurement methods/rules allow for simpler, less extensive measurements that group numerous items despite their dissimilarity in site operation/execution. And treat significant items of work process/trade as "deemed to be included" in the measurement covered. The reason being to give room for the large size, complex nature and technological processes involved in the planning and execution of such heavy capital projects.

This creates problems during pricing for the bidder or contractor who may not have skill/time to properly assess the "deemed to be included" measurements, thereby increasing pricing accuracy risk of projects.

Also, such grouping of significant work items create problem in cost management when pricing variations at post contract stage. Examples include industrial pipes measured linear with depth of trench, leaving pipe trench excavation, disposal and earthwork support to be assessed by bidder during pricing. $[8,9]$

\section{Cost Code:}

Cost code are developed for components and works in the four areas of chemical plant. Modern cost code must satisfy the plant owner and contractor and be adaptable to computers and machine accounting. It must provide cost feedback for researching the cost patterns of the four areas of chemical plant and their subcomponents and provide detailed data required by contractors [10].

Thus the main purpose of modern cost code include:-

- To provide cost feedback for estimating purposes in the most efficient form.

- Provide framework for facilitating the control of construction labour, material and contracts.

- Provide information for compiling capital asset ledger.

- Provide cost breakdown that are useful to divisions in developing reliable product and distributive costs.

- Guarantee maximum accuracy in costing by being easy to understand and apply by contractor and client.

- Give flexibility in extending, contracting and updating costs.

- Orient code toward machine and computer accounting.

The cost code serve as an excellent checklist of all items that must be considered in making an estimate. It presents in the first column all main components of a project in the four area concept, thus providing mechanism for collecting the cost feedback in a desired and consistent manner. This enables the cost/capacity patterns of the different (four) areas of chemical plant to be charted in one graph and compared to make for efficient cost management. (See figure 2)

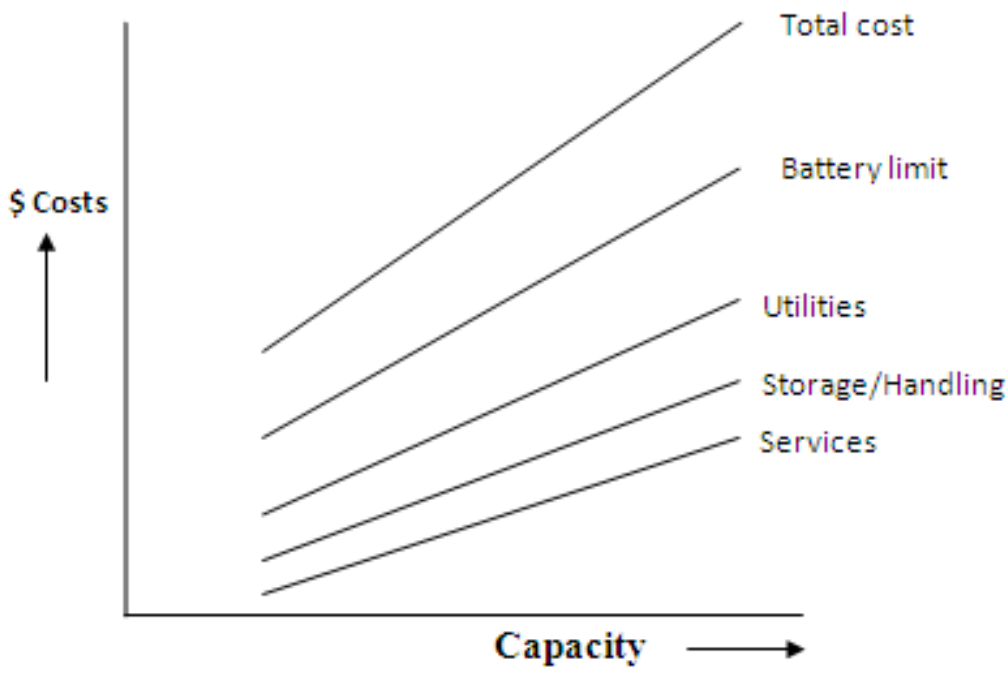

Figure 2: Cost graphs of four areas of chemical plant. 
Each area is a subsystem of an integrated plant system and must be cost-optimized for the chemical plant as a system to be operationally efficient and sustainable. Knowledge of the optimum costs of each area for a given capacity enables the total cost of complete plant to be synthesized and serve as a coarse cost plan for a proposed process plant.

As stated earlier, estimating costs of process projects are done using techniques ranging from conceptual/order of magnitude methods to deterministic or detailed methods (See Table 1).

\section{Cost Estimate Classification Matrix for the Process Industries.}

AACEI Recommended cost Estimate Classification system No. 17R-97 has five classes.

The five estimate classes are presented in table 1 below, in relationship to the identified characteristics. But only the level of project definition primarily determines the estimate class. The other four characteristics are secondary characteristics that are generally correlated with the level of project definition. The estimate classification matrix supplement the generic standard. The characteristics are typical for the process industries but may vary from application to application.

Table I Cost Estimate Classification Matrix for Process Industries

\begin{tabular}{|c|c|c|c|c|c|}
\hline \multirow[b]{2}{*}{$\begin{array}{l}\text { ESTIMATE } \\
\text { CLASS }\end{array}$} & \multirow{2}{*}{$\begin{array}{ll}\text { Primary } & \\
\text { Characteristic } & \\
\text { LEVEL } & \text { OF } \\
\text { PROJECT } & \\
\text { DEFINITION } & \\
\end{array}$} & \multicolumn{4}{|c|}{ Secondary characteristics } \\
\hline & & END USAGE & METHODOLOGY & $\begin{array}{l}\text { EXPECTED } \\
\text { ACCURACY } \\
\text { RANGE }\end{array}$ & $\begin{array}{l}\text { PREPARATION } \\
\text { EFFORT }\end{array}$ \\
\hline & $\begin{array}{l}\text { Expressed as \% of } \\
\text { complete definition }\end{array}$ & $\begin{array}{l}\text { Typical } \\
\text { purpose } \\
\text { estimate }\end{array}$ & $\begin{array}{l}\text { Typical estimating } \\
\text { method }\end{array}$ & $\begin{array}{l}\text { Typical variation in } \\
\text { low/high ranges (a) }\end{array}$ & $\begin{array}{l}\text { Typical degrees of } \\
\text { effort relative to least } \\
\text { cost index } 1 \text { (b). }\end{array}$ \\
\hline Class 5 & $0 \%$ to $2 \%$ & $\begin{array}{l}\text { Concept } \\
\text { screening }\end{array}$ & $\begin{array}{lr}\begin{array}{lr}\text { Capacity } & \text { Factored } \\
\text { parametric } & \text { models } \\
\text { judgment or } & \text { Analogy }\end{array} \\
\end{array}$ & $\begin{array}{l}\mathrm{L}-20 \% \text { to }-50 \% \\
\mathrm{H}+30 \% \text { to }+100 \%\end{array}$ & 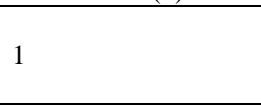 \\
\hline Class 4 & $1 \%$ to $15 \%$ & $\begin{array}{ll}\text { Study of } \\
\text { Feasibility }\end{array}$ & $\begin{array}{l}\text { Equipment factored or } \\
\text { Parametric models }\end{array}$ & $\begin{array}{l}\mathrm{L}-15 \% \text { to }-30 \% \\
\mathrm{H}+20 \% \text { to }+50 \%\end{array}$ & 2 to 4 \\
\hline Class 3 & $10 \%$ to $40 \%$ & $\begin{array}{l}\text { Budget } \\
\text { Authorization } \\
\text { or control } \\
\end{array}$ & $\begin{array}{l}\text { Semi-detailed Unit } \\
\text { costs with Assembly } \\
\text { level line items }\end{array}$ & $\begin{array}{l}\mathrm{L}-10 \% \text { to }-20 \% \\
\mathrm{H}+10 \% \text { to }+30 \%\end{array}$ & 3 to 10 \\
\hline Class 2 & $30 \%$ to $70 \%$ & $\begin{array}{ll}\text { Control } & \text { or } \\
\text { Bid/Tender } & \end{array}$ & $\begin{array}{l}\text { Detailed Unit Cost } \\
\text { with forced detailed } \\
\text { Take-off }\end{array}$ & $\begin{array}{l}\mathrm{L}-5 \% \text { to }-15 \% \\
\mathrm{H}+5 \% \text { to }+20 \%\end{array}$ & 4 to 20 \\
\hline Class 1 & $50 \%$ to $100 \%$ & $\begin{array}{l}\text { Check } \\
\text { Estimate or } \\
\text { Bid/Tender }\end{array}$ & $\begin{array}{l}\text { Detailed Unit cost with } \\
\text { Detailed Take-off }\end{array}$ & $\begin{array}{l}\mathrm{L}-3 \% \text { to }-10 \% \\
\mathrm{H}+3 \% \text { to }+15 \%\end{array}$ & $\begin{array}{l}5 \text { to } 100 \text { or } 0.5 \% \text { of } \\
\text { project cost. }\end{array}$ \\
\hline
\end{tabular}

Key: $b$ where cost index value 1 may represent $0.005 \%$ of project cost and 100 index value represents $0.5 \%$ of project cost

4.1 Estimate input check list/maturity level

Included in the supplemental guideline for the process industries is a chart showing maturity of estimate input or project definition deliverables against the classes of estimate (See TABLE 2).

Table 2 Estimate Input checklist and Maturity Matrix for the Process Industries

\begin{tabular}{|c|c|c|c|c|c|}
\hline & \multicolumn{5}{|c|}{ ESTIMATE CLASSIFICATION } \\
\hline General Project Data: & CLASS 5 & CLASS 4 & CLASS 3 & CLASS 2 & CLASS 1 \\
\hline Project Scope Description & General & Preliminary & Defined & Defined & Defined \\
\hline Plant Production/Facility Capacity & Assumed & Preliminary & Defined & Defined & Defined \\
\hline Plant Location & General & Approximate & Specific & Specific & Specific \\
\hline Soils \& Hydrology & None & Preliminary & Defined & Defined & Defined \\
\hline Integrated Project Plan & None & Preliminary & Defined & Defined & Defined \\
\hline Project Master Schedule & None & Preliminary & Defined & Defined & Defined \\
\hline Work Breakdown Structure (WBS) & None & Preliminary & Defined & Defined & Defined \\
\hline Project Code of Accounts & None & Preliminary & Defined & Defined & Defined \\
\hline Contracting strategy & Assumed & Assumed & Preliminary & Defined & Defined \\
\hline \multicolumn{6}{|l|}{ Engineering Deliverables: } \\
\hline Block Flow Diagrams & $\mathrm{S} / \mathrm{P}$ & $\mathrm{P} / \mathrm{C}$ & $\mathrm{C}$ & $\mathrm{C}$ & $\mathrm{C}$ \\
\hline Plot Plans & & $\mathrm{S}$ & $\mathrm{P} / \mathrm{C}$ & $\mathrm{C}$ & $\mathrm{C}$ \\
\hline Process Flow Diagrams (PFDs) & & $\mathrm{S} / \mathrm{P}$ & $\mathrm{P} / \mathrm{C}$ & $\mathrm{C}$ & $\mathrm{C}$ \\
\hline Utility Flow Diagrams (UFDs) & & $\mathrm{S} / \mathrm{P}$ & $\mathrm{P} / \mathrm{C}$ & $\mathrm{C}$ & $\mathrm{C}$ \\
\hline Piping \& Instrument diagrams (P\&IDs) & & $\mathrm{S}$ & $\mathrm{P} / \mathrm{C}$ & $\mathrm{C}$ & $\mathrm{C}$ \\
\hline Heat and Material Balances & & $\mathrm{S}$ & $\mathrm{P} / \mathrm{C}$ & $\mathrm{C}$ & $\mathrm{C}$ \\
\hline Process Equipment List & & $\mathrm{S} / \mathrm{P}$ & $\mathrm{P} / \mathrm{C}$ & $\mathrm{C}$ & $\mathrm{C}$ \\
\hline
\end{tabular}


Costing of Oil and Gas Projects for Efficient Management and Sustainability

\begin{tabular}{|l|l|l|l|l|l|}
\hline Utility Equipment List & & $\mathrm{S} / \mathrm{P}$ & $\mathrm{P} / \mathrm{C}$ & $\mathrm{C}$ & $\mathrm{C}$ \\
\hline Electrical One-Line Drawing & & $\mathrm{S} / \mathrm{P}$ & $\mathrm{P} / \mathrm{C}$ & $\mathrm{C}$ \\
\hline Specifications \& Datasheets & $\mathrm{S}$ & $\mathrm{P} / \mathrm{C}$ & $\mathrm{C}$ \\
\hline General Equipment Arrangement Drawings & $\mathrm{S}$ & $\mathrm{P} / \mathrm{C}$ & $\mathrm{C}$ \\
\hline Spare Parts Listings & & & $\mathrm{P} / \mathrm{P}$ & $\mathrm{C}$ \\
\hline Mechanical Discipline Drawings & & $\mathrm{S}$ & $\mathrm{C}$ \\
\hline Electrical discipline Drawings & & $\mathrm{S}$ & $\mathrm{P}$ & $\mathrm{P}$ \\
\hline $\begin{array}{l}\text { Instrumentation/Control System Discipline } \\
\text { Drawings }\end{array}$ & & $\mathrm{S}$ & $\mathrm{P}$ & $\mathrm{P} / \mathrm{C}$ \\
\hline Civil/Structural/Site Discipline Drawings & & & $\mathrm{P} / \mathrm{C}$ \\
\hline
\end{tabular}

Source: AACEI, Input Checklist and Maturity Matrix

This is a checklist of basic deliverables in process industries. The maturity level is an approximation of the degree of completion of the deliverable.

The degree of deliverable is indicated by the following letters:

- None (blank) - Development of the deliverable has not yet begun.

- Started (S) - Work on the deliverable has begun.

Development is typically limited to sketches, rough out-lines, or similar levels of early completion.

- Preliminary $(\mathrm{P})$ - Work on the deliverable is advanced.

Interim cross-functional reviews have usually been conducted. Development may be near completion except for final reviews and approvals.

- Complete (C) - The deliverable has been reviewed and approved as appropriate.

\section{Estimating Methodologies}

As can be seen from the cost estimate classification matrices as the level of project definition increases, the estimating methodology tends to progress from conceptual (stochastic or factored) methods to deterministic methods.

With conceptual estimating methods the independent variables used in the estimating algorithm are generally analyzed cost models (cost per unit, per $\mathrm{m} 2, \mathrm{~m} 3, \mathrm{~m}, \mathrm{kv}$, etc) factored to reflect condition of proposed project.

Project definition is low and estimate accuracy range is wide $( \pm 30-50 \%)$, with estimate quality depending on adequacy of factors and estimator's skill and judgment in adjusting the factors to reflect the specifications of proposed project and quality/integrity of historic cost data being factored. Conceptual estimates are used for early project screening, evaluating general projects feasibility, evaluating project alternative locations, technologies and capacities costs. It is also used to establish preliminary cost budget that control project design as class 3 estimate where accuracy range may be $\pm 20 \%$.

\subsection{For Budget Estimate}

\section{- $\quad$ Site conditions are known.}

- The plant layout has been prepared by the plant layout and piping group.

- Process Flow Diagrams (PFDs) and preliminary piping and instrumentation (P\&IDs) have been prepared by the process Engineering group.

- The preliminary (major) Equipment list with equipment weights and capacities has been prepared by the process Engineering group.

- The contracting and sub contracting philosophies have been worked out and budget quotes have been obtained from equipment vendors for the major items of equipment.

- Estimates of bulk materials can be made from the preliminary drawings available.

- Labour and productivity rates are available

- Preliminary construction and manpower schedules have been prepared.

At this stage the client may pursue the project or abandon it, if the viability is still suspected.

\subsection{For Deterministic Estimating}

The independent variables or work items' costs are deduced through direct/quantitative measurement which requires substantial amount of effort and time (eg weeks, months) to prepare. (ie class 3 through to class 1 estimates). Project definition level is high and estimate accuracy range narrows progressively down towards \pm 5 $10 \%$ for $100 \%$ definition.

The minimum required engineering and design data to prepare a detailed estimate for chemical process plants, include:-

Process and utility flow drawings, piping and instrument drawings (P\&ID), equipment data sheets, motor lists, electrical one-line diagrams, piping isometrics (for alloy and large diameter piping), equipment and 
piping layout drawings, plot plans and engineering specifications which as shown in the maturity matrix chart have been reviewed and approved as appropriate.

Pricing data should include vendor quotations, current price from recent purchase orders, current labour rates, sub contract quotations, projects schedule information (to help determine escalation requirements) and the construction plan (to determine labour productivity and other adjustments).

For a completely detailed estimate, all costs are detailed including the Direct Field Cost DFC, Indirect Field Cost IFC, Home Office Costs HOC and all other miscellaneous costs for both the inside Battery limit ISBL and outside Battery limit OSBL facilities.

Of course any particular estimate may involve a combination of conceptual and deterministic methods. One variant of the detailed estimate is a semi-detailed estimate in which the costs for the ISBL process facilities are factored, and the costs for the OSBL facilities are detailed.

Another variant is the forced-detailed estimate in which detailed estimating methods are used with incomplete design information. Here, detailed take-off quantities are generated from preliminary drawing and design information.

\subsection{Activities undertaken in Preparing Estimates}

Conceptual Estimate Activities (Order of Magnitude OOM): Activities undertaken in preparing conceptual cost estimates vary with the type of conceptual estimate:- Unit method; physical dimensions' $\left(\mathrm{M}^{2}\right.$, $\mathrm{M}^{3}$, LM) method, capacity/scale factor method, Various Factor methods (Lang, Hand, Millars enhancement factors for size, metallurgy and operating pressure. Discipline-specific equipment factor that generate separate costs for each of the disciplines associated with the installation of equipment e.g. equipment installation labour, concrete, structural steel, piping, electrical, instruments, painting, insulation) and parametric modeling [11].

Generally, adjustments are required in the cost estimates to take care of escalations, location and other features specific to the proposed project. For order of magnitude estimate, adjustments may be undertaken in 3 stages.

First determine the capacity, the final cost, year of completion and location of the adopted project and then apply adjustments.

Stage 1: Escalate the cost of the completed project to obtain the current cost, by multiplying the computed cost (say US $\$ 900$ million) by a realistic factor (say X 150\%) to reflect the escalation which may have taken place between the date of completion of the project and the current date. The escalation factor is usually obtained from published national/international cost indices, or from a company's computer cost database and checked with actual suppliers.

Stage 2: Adjust the cost of the completed project to take care of differences in location. This is achieved by applying a location factor (say x120\%). The location factor is intended to reflect the differences in accessibility, terrain, labour availability etc.

Stage 3: Other adjustments may be made by adding or subtracting specific amounts to reflect other areas in which the current project differs from the previous one for example, pollution control requirements, abnormal client, project team requirements etc.

\subsection{Steps in Costing /Cost Estimating [12]}

- Review the scope of the work/prepare project Estimate basis and schedule

- Engineering scope

- Procurement scope

- Construction scope

See Appendix 1 for the key points to be noted.

- Define the Work Breakdown structure (WBS)

(See Appendix 2 for a sample)

- Complete the cost Estimation Condition Form

(See Appendix 4 for sample)

- Prepare a cost codes Table using the WBS earlier defined

- Prepare an equipment List. This should be done in consultation with the Engineering, Procurement and Construction Departments to ensure that no major items of equipment are omitted (See Appendix 5 for a sample)

- Workout the unit cost of procuring each item of equipment. This is usually derived from the analysis of previous projects and by inquiring from vendors/suppliers

- Workout the unit costs for installing each item of equipment. This is obtained from the analysis of previous projects 
- Estimate from Materials Take-off or by interpolation from previous projects, the quantity of bulk materials required e.g.: cubic meters of concrete, tons of reinforcement, tons of piping, sets of control values etc. and thus prepare Direct Field Cost (DFC) estimate.

- Prepare the estimation data for all Indirect Costs including contractors project fee estimates etc and Transportation costs, which is the volume of each type of equipment or bulk material multiplied by the unit price for transportation, and thus prepare Indirect Field Costs (IFC) estimate.

- $\quad$ Prepare Home Office Cost (HOC) estimate usually about 30\% of the supply portion of the contract price (i.e. Direct Field Cost DFC)

- $\quad$ Field Office Costs: about $20 \%$ of the Field portion of the contract price

- Pre-commissioning and commissioning costs about $10 \%$ of total cost of equipment.

- Prepare safety/Escalation/Contingency Costs:-allow a lump sum derived from previous project experience or about $15 \%$.

- $\quad$ Review/Validate estimates.

- Load Lotus 1-2-3. Release 3.1 and using the standard estimation sheet and data from the foregoing costing steps prepare the cost estimates, cost code by cost code. Two or more cost codes should not be estimated on one sheet.

- Transfer the subtotals for each cost code to the estimate summary sheet. This gives the total project cost estimate.

- Check the accuracy of the estimation using any computer programme capable of performing the Monte Carlo simulation.

- Exit Lotus 1-2-3, load word perfect 5.1 and prepare as before a suitable transmittal letter/memo forwarding the cost estimate to the relevant parties [13].

\subsection{Illustrative Models of Process Plant Cost Estimate:}

\subsubsection{End product Unit Model}

Relate historical construction cost data e.g. of Electric generating plant to unit cost per kilowatt and use it to multiply total kilowatts of a proposed plant.

Relate constructed cost of hospital to cost per patient bed and use it to multiply total bed spaces of a proposed hospital etc.

\subsubsection{Physical Dimension Method}

Relate constructed cost of facility to its cost per Length, Area, Volume etc. and use it to multiply total Length, Area or Volume respectively of proposed similar facility.

These methods believe that there is linear relationship between size and cost, and ignore cost impact of "economies of scale" of proposed facility in the estimate, as well as time and location impacts.

\subsubsection{Capacity Factor (Exponential or Six-tenth Factor) Method}

This relies on Non-Linear Relationship between capacity and cost that is the existence of economies of scale.

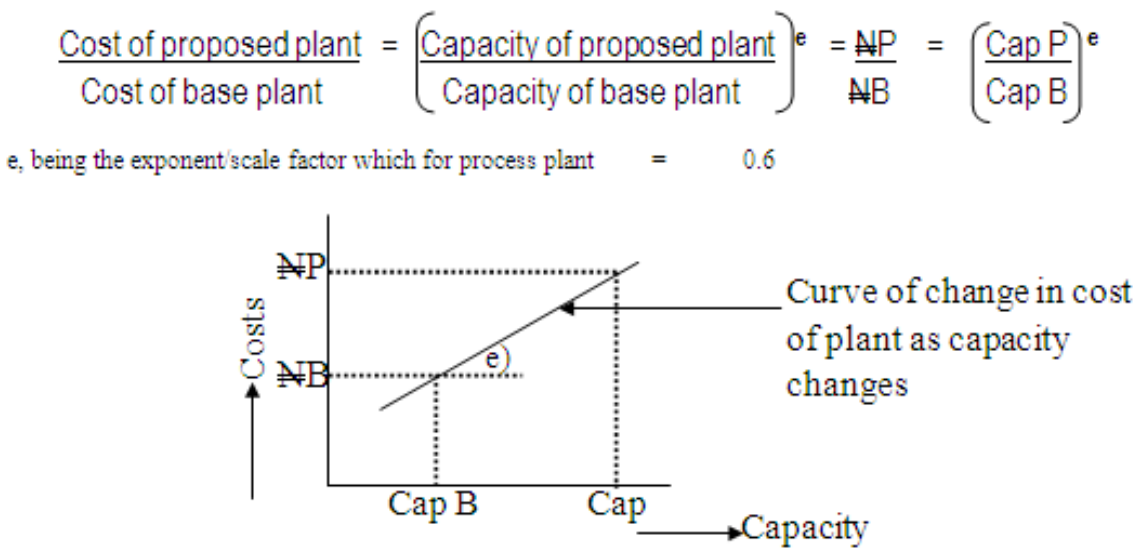

Figure 3: Capacity factor relationship (Log - Log Graph)

When capacity of plant reaches limit of existing technology, the exponent assumes a value of 1 i.e. cost and capacity curve become linear and at this point it becomes better to build two facilities of smaller size than one large facility. If you use low exponent for new large plant relative to small base plant, you will underestimate costs of the proposed plant. For greater accuracy it is better to break total plant cost into cost sections and apply 
suitable exponent for each cost section. Individual items' exponential cost estimating gives greater accuracy and provides item baselines for cost control purposes.

Although published data on capacity factors exist, the best data should come from your organization and requires commitment to maintain.

\subsubsection{Hypothetical Example:}

Capacity factor cost estimating for proposed $300000 \mathrm{bbl} /$ day Refinery Plant in Otuocha Anambra state using cost data from $200000 \mathrm{bbl} /$ day Warri Refinery plant completed in 2004 at $\$ 100 \mathrm{~m}$. To save, space, basic assumptions are built into the analysis

Total construction cost of a refinery of $200,000 \mathrm{bbl} /$ day capacity in

Warri Delta State, completed in 2004.

Less $\$ 5 \mathrm{~m}$ cost of items peculiar to Warri Plant $(100-5)$

5.5.4 Adjustments

(1) Adjust for capacity based on exponential law $\$ 95 \mathrm{x}$ (200000) $=\$ 121.2 \mathrm{~m}$

(2) Adjust for inflation $(\mathrm{r}=8 \%)$ between 2004 to 2014 , (121.2) $(1.08)^{10}=\$ 261.66 \mathrm{~m}$

(3) Adjust for location index (Warri 0.92 - Otuocha 1.14)

$=\$ 324.23 \mathrm{~m}$

$$
\text { Add (\$17m) New Pollution Equipment at Otuocha Plant } \$ 324.23+\$ 17=\$ 341.23 \mathrm{~m}
$$

$\$ 337.82 \mathrm{~m}$

Reduction in Contingency ( $1 \%$ better weather for Otuocha Plant) i.e. $\$ 341.23 \times 0.99 \quad=\$ 337.8 \mathrm{~m}=$

Capacity Factor (Order of Magnitude) estimate for proposed Otuocha Refinery Project in 2014 is \$337.82Million.

The capacity factor estimates is often used to support decision making at the pre design stage of a project.

5.5.5 Factor estimating Methods: These are used in process plant estimating where total cost of an item or facility can be reliably estimated from the costs of a primary component or specialized process equipment that make up significant portion $(40 \%)$ of the project cost.

5.5.6 Equipment Factored Estimates:- are used to develop costs for process and utility units where the costs of direct labour and bulk materials used to construct the facilities is correlated with the costs of the major equipment. A factor exists between cost of an equipment item and costs of the associated non equipment items (foundation, piping, electrical, etc) needed to fully install the equipment. Hence equipment list has to be available at this class 4 estimate level with $1-15 \%$ project definition.

Equipment Factor method is used for feasibility estimate to determine whether there is sufficient business case to pursue the project and if so to justify the funding of engineering/design required to generate project budget (class 3 estimate).

Some Factors exist to estimate DFC, while some total installed costs TIC. Lang factor estimate total cost of plant using single factor.

Total Plant Cost $(\mathrm{TPC})=$ Total estimated equipments cost $\mathrm{x}$ Lang factor

For example $\quad$ TPC $=\$ 1.5 \mathrm{~m} \times 4.74=\$ 7.11 \mathrm{~m}$ for Fluid process

Lang factor varies for solid 3.1; solid - fluid 3.63, and Fluid process plant 4.74

Hand Factor, provide factors (ranging from 2.4 to 4.3) for different types of process equipment e.g. column, vessel, heat exchangers etc. Each factor covering costs of associated works used to install/ support the particular equipments (e.g. labour, concrete structural steel, piping, electrical, instruments, painting, insulation). But excluding indirect field costs (IFC), home office costs HOC, and costs for offsite or outside battery limit facilities which are estimated separately.

A variant of Factor Estimating breakdown the cost into major components such as -piping, electric, buildings etc and provide separate factors for each component thus, the aggregate of component or main plant item (MPI) costs multiplied by their indicated factors (F) gives the total erected plant cost i.e.

$$
\sum_{1}^{n} \text { MPIC }+\sum_{1}^{n} F(\text { MPIC) }
$$

\subsubsection{Hirson and Glazier Factor Model:}

This model evolved from statistical study of 42 Refining Petrochemical and synthetic fuel plants. It allowed factors for many variables that do create inaccuracies in estimating and has an accuracy range of \pm $25 / 30 \%$ of total direct investments.

It consist of series of factors applied against the cost of the basic process equipment (in carbon steel) plus an incremental cost to allow for alloys plus field erected items. Thus Hirson and Glazier Factor Model: 
$\mathrm{I}=\mathrm{E}[\mathrm{A}(\mathrm{I}+\mathrm{FL}+\mathrm{Fp}+\mathrm{Fy}]+\mathrm{B}+\mathrm{C}$

Where:

I $=$ Battery Limits Investment

$\mathrm{E} \quad=$ Indirect cost factor representing contractors' overhead/profit, engineering supervision and contingencies

A $\quad=$ Estimated total cost of all battery limits equipment (carbon steel) on Free on Board FOB basis

FL $\quad=$ Cost factor for field labour

Fp $\quad=$ Cost factor for piping materials

Fy = Cost factor for miscellaneous items

$\mathrm{B} \quad=$ Erection cost of all equipment estimated (Furnaces, tanks etc)

$\mathrm{C} \quad=$ Incremental cost of alloy materials used for corrosion resistant properties.

As indicated earlier, the best approach will be to use individual component capacity factor and its erection factor

such that the aggregate $\sum$ of all the equipment components costs plus the individual equipment erection costs will give the total plant cost. This facilitates efficient cost management and allow for measuring variations in cost of individual equipment replacement resulting from improved technology.

Another example of using Hand's Equipment Factoring techniques is illustrated in table 3 below [14].

Here, the total cost of all equipment items for each type of equipment was multiplied by a factor for that specific type of equipment to derive the DFC for that equipment type. For instance the total cost of all vertical vessels $(\$ 540 \mathrm{k}$ ) was multiplied by an equipment factor of 3.2 (table 3) to obtain an installed DFC of $\$ 1728 k$. Direct Field Labour (DFL) was estimated at 25 percent of (DFC) or $\$ 1,938 \mathrm{k}$. The IFC were then estimated at 115 percent of the DFL costs, totaling $\$ 2,229 \mathrm{k}$. The sum of the DFC and IFC costs make up the Total Field Costs (TFC) of $\$ 9,982 \mathrm{k}$. HOC are factored as $30 \%$ of DFC, which totals $\$ 2,326 \mathrm{k}$. For this estimate, the project commissioning costs were factored as $3 \%$ of DFC, and contingency was factored as $15 \%$. The Total Installed Cost (TIC) for this estimate thus totals $\$ 14,422 \mathrm{k}$.

Worthy of note is the various equipment factors displayed in this example. Total equipment cost to DFC is a factor of 2.8 (a typical range is 2.4 to 3:5). Total equipment cost to TFC is a factor of 3.6 (with a typical range being 3.0 to 4.2 ). Total Equipment cost to total project cost including contingency is a factor of 5.1 (a typical range is 4.2 to 5.5) close to Lang's overall equipment factor of 4.74 for fluid plant.

This and other methods can yield estimate suitable for the appropriation of funds provided that the equipment costs are reliable, underlining the need for application of value engineering to investigate and firm up appropriate equipment requirements and costs; while the factors take care of the balance. Thus the client, sponsors, and promoters should provide sufficient finance required to generate and develop the information necessary to permit the cost Engineer/Quantity Surveyor to arrive at realistic project cost estimate. 
Table 3: Illustration of Total Process Plant Cost Using Equipment Factored Estimating

\begin{tabular}{|c|c|c|c|c|c|c|c|c|}
\hline Acc & Item Description & Adj & Costs & & & & Eqmet & \\
\hline No & & Factor & Labour 5 & Eqmi 5 & $\begin{array}{l}\text { Eqmt } \\
\text { Factor }\end{array}$ & Total & Mult & Total \\
\hline 51 & Columns & & & 650,000 & 2.1 & $1,365,000$ & & \\
\hline 52 & Vertical Vessels & & & 540,000 & 32. & $1,728,000$ & & \\
\hline 53 & HorizontalVatsals & & & 110,000 & 24 & 264,000 & & \\
\hline 54 & Shell \& Tube Hext exchangers & & & 630,000 & 25 & $1,575,000$ & & \\
\hline 55 & Plate Hent Exchangers & & & 110,000 & 20 & 220,000 & & \\
\hline 56 & Pumps, Motor Driven & & & 765,000 & 3.4 & $2,601,000$ & & \\
\hline & & & & $\begin{array}{l}2,805,00 \\
0\end{array}$ & & & & \\
\hline & DIRECT FIELD COSTS & $25 \%$ & $1,938,000$ & & & $7,753,000$ & 2.8 & $53.8 \%$ \\
\hline & & OFDFC & & & & & & \\
\hline 10 & Temporary Construction Facilities & & & & & & & \\
\hline 11 & $\begin{array}{l}\text { Construction } \\
\text { Services Supplies Consumables }\end{array}$ & & & & & & & \\
\hline 12 & Field Steff Subsistence Expense & & & & & & & \\
\hline 13 & Peyroll Burdens Benefits linsurence & & & & & & & \\
\hline 14 & Construction Equipment Tools & & & & & & & \\
\hline 15 & Intemztional Expense & & & & & & & \\
\hline & INDIRECT FIELD COSTS & $115 \%$ & & & & $2,229,000$ & & $15.5 \%$ \\
\hline & & OfDFL & & & & & & \\
\hline 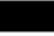 & TOTAL FINLD COSTS & & & & & 2,000 & & 69256 \\
\hline & & & & & & & & \\
\hline 20 & Project Nanagement & & & & & & & \\
\hline 21 & Project Controls Estimating & & & & & & & \\
\hline 22 & Project Procurement & & & & & & & \\
\hline 23 & Project Construction Nenzagment & & & & & & & \\
\hline 24 & Enginetring Design & & & & & & & \\
\hline 25 & Homa Office Expensas & & & & & & & \\
\hline & HONIE OFFICE COSTS & 3040 & & & & $2,326,000$ & & $16.1 \%$ \\
\hline & & OFDFC & & & & & & \\
\hline & TOTAL FIXLD AND HONI OFF & & & & & $12,308,000$ & 4.4 & \\
\hline & COSTS & & & & & & & \\
\hline & & & & & & & & \\
\hline 30 & Owner's Costs & & & & & & & \\
\hline 31 & Project Commissioning Costs & $3 \%$ & OFDFC & & & 233,000 & & \\
\hline 32 & Escalation & & & & & & & \\
\hline 33 & Other Non-Assignable costs & & & & & & & \\
\hline 34 & Contingency & $15 \%$ & Of above & & & $1,881,000$ & & \\
\hline 35 & Fes & & & & & & & \\
\hline & OTHER FROJECT COSTS & & & & & $2,114,000$ & & $14.7 \%$ \\
\hline & & & & & & & & \\
\hline & TOTAL FROJXCT COSTS & & & & & $\$ 14,422,000$ & 5.1 & 100.05 \\
\hline
\end{tabular}

Source: Culled from [14]

Sample breakdown of a detailed estimate is shown in table 3.1 
Table 3.1 Sample Breakdown Of A Detailed Estimate

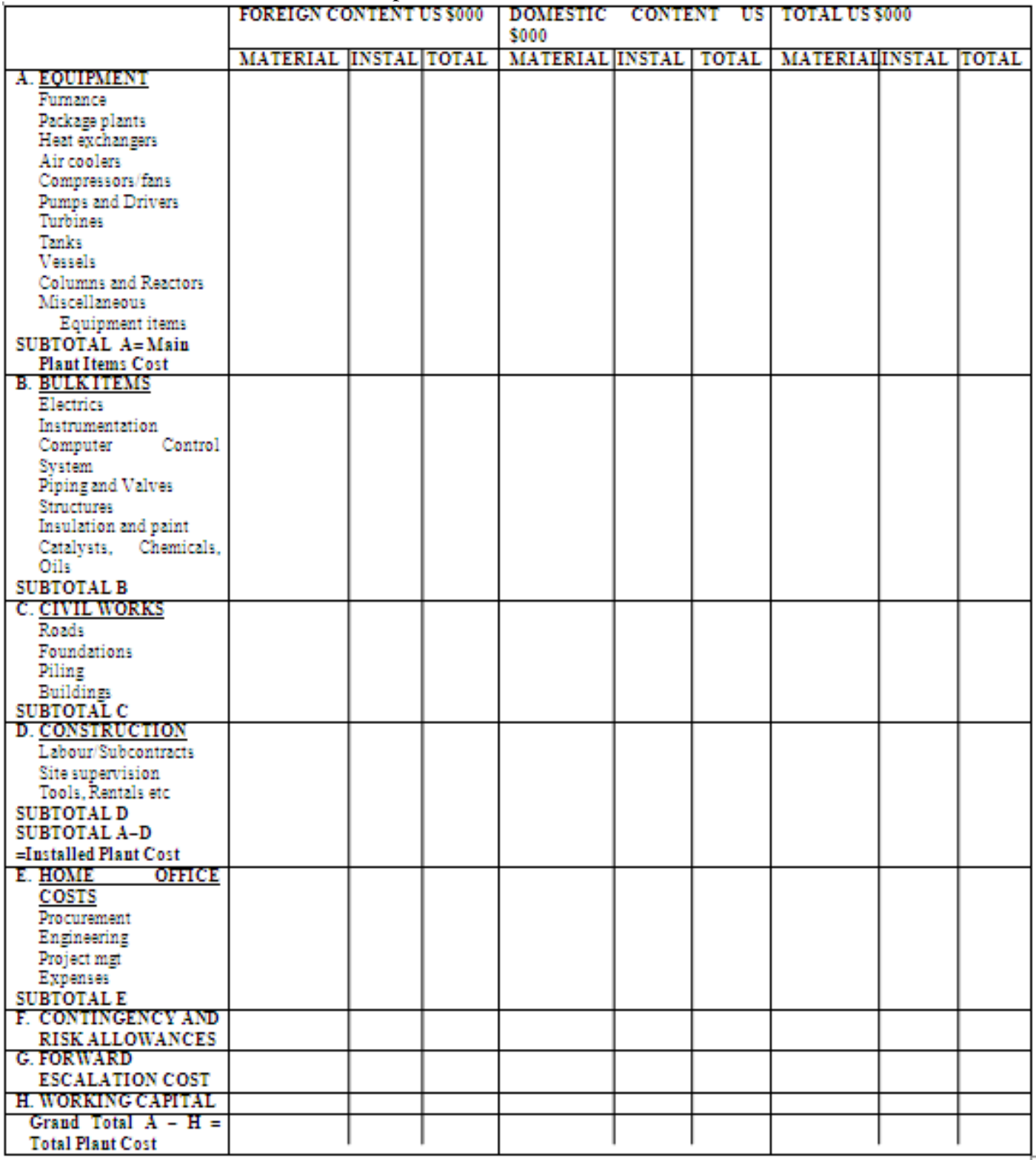

Source: Authors Survey 2014

It is rendered in foreign and domestic cost components to support efficient cost management

\section{Efficient Management Of Oil And Gas Projects}

Adding value to the economy through oil and gas projects goes beyond estimating project cost. The project estimates must be cost - managed.

To achieve efficient management of oil and gas project at implementation, there has to be proper integration of the evolved estimate, cost control system and schedule system. Information must be shared between estimate, schedule and cost control systems.

The estimates provide labour hours and craft breakdowns essential to determining schedule activity durations and resource loading. It also provides costs and quantities to the cost control system.

The schedule provides the starting and ending dates using resource loading for project items construction in the estimate.

The cost control system time-phase or spread cost through the items' scheduled installation periods on weekly or monthly basis (see table 4, project cost cash flows). The vertically aggregated total weekly or monthly costs provide project cost baseline or budgeted costs of work scheduled (BCWS). This enables actual construction performance in terms of cost, time, quantity/quality to be integratively monitored and compared with the baselines (budgeted cost, scheduled time and performance) at a given milestones using Earned value system metrics. It also enables cost reporting systems' record of labour and material expenditures to be 
correlated with schedule progress. And the remaining durations for scheduled activities correlated to the forecast completion date in the cost system. In this way adverse variance will then be located for corrective actions, while positive variance are upheld/enhanced.

Cost system estimate, monitor and control cost while schedule system plans, monitors and controls time. Hence our goal in Estimate/Cost/Schedule integration is to align estimate cost data and schedule data at a level to support integration and ensure efficient management of the project process. Sufficient level of detail for estimate (cost) and schedule are required to interface/correlate cost and schedule. Do not attempt to integrate at too much detail nor too high of a summary level. Using sufficient level of detail for integration requires that the quantity surveyor/cost engineer or estimator and scheduler review the WBS and determine the level at which cost items and schedule activities can be correlated to generate admissible/updatable cost baselines for efficient cost management of oil and gas projects.

The Basic Earned Value Management Models/Metrics are simply illustrated below for a hypothetical process project. (See Tables 4 and 5).

\section{$\underline{\text { KEY }}$}

BCWS $\quad=\quad$ Budgeted Cost of Work Scheduled

BCWP $\quad=\quad$ Budgeted Cost of Work Performed

ACWP $\quad=\quad$ Actual Cost of Work Performed

SV $\quad=\quad$ Schedule Variance

$\mathrm{CV} \quad=\quad$ Cost Variance

CPI $\quad=\quad$ Cost Performance Index

SPI = Schedule performance Index

Percentage Complete (On Budget)

Percentage Complete (On Forecast Total Cost)

$\begin{array}{ll}= & \mathrm{BCWP}-\mathrm{BCWS} \\ = & \mathrm{BCWP}-\mathrm{ACWP} \\ = & \mathrm{BCWP} / \mathrm{ACWP} \\ = & \mathrm{BCWP} / \mathrm{BCWS} \\ = & \mathrm{BCWP} / \mathrm{BAC} \\ = & \mathrm{ACWP} / \mathrm{EAC}\end{array}$

Table 4: Scheduling/Programming Process Project to Produce Budget Baseline for Cost Control Purposes.

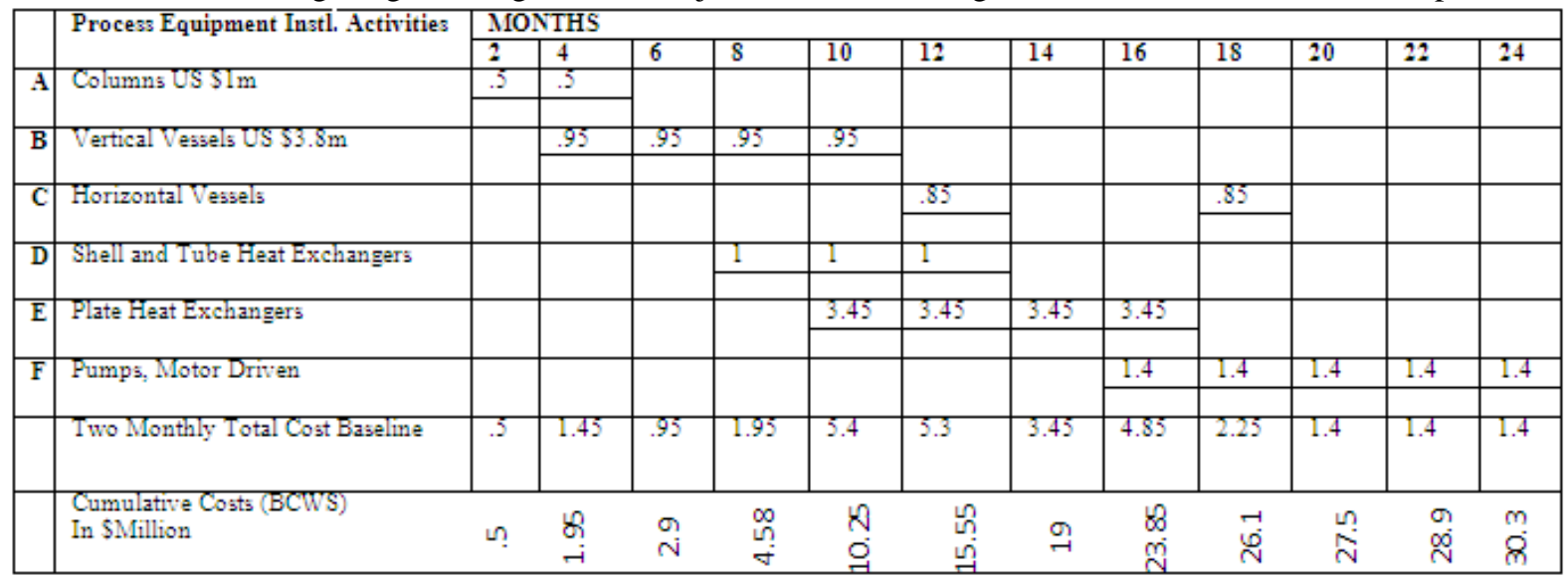

Source: Author's Field Survey, Budget Baseline Chart 2014

Table 5: Cost Reporting For Process Project (At Month 10) Using Earned Value Technique.

\begin{tabular}{|l|l|l|l|}
\hline MONTH & ACWP & BCWP & BCWS \\
\hline 2 & .45 & .45 & 0.5 \\
\hline 4 & 1.49 & 1.45 & 1.45 \\
\hline 6 & 0.99 & 0.95 & .95 \\
\hline 8 & 2.34 & 2.45 & 1.95 \\
\hline 10 & 6.48 & 7.02 & 5.4 \\
\hline $\begin{array}{l}\text { Cumulative Cost at Month 10 } \\
\text { (US \$M) }\end{array}$ & $\mathbf{1 1 . 7 1}$ & $\mathbf{1 2 . 3 2}$ & $\mathbf{1 0 . 2 5}$ \\
\hline
\end{tabular}

Source: Author's Field Survey, Earned Value Application 2014

Schedule Variance SV

Cost Variance CV

Cost Performance Index CPI =

Schedule Performance Index SPI =

Percent Complete (on Budget) =

$\begin{array}{ll}= & \mathrm{BCWP}-\mathrm{BCWS}=12.32-10.25=2.07 \\ = & \mathrm{BCWP}-\mathrm{ACWP}=12.32-11.71=0.61 \\ = & \frac{B C W P}{A C W P}=\frac{12.32}{11.71}=1.05 \\ = & \frac{B C W P}{B C W / S}=\frac{12.32}{10.25}=1.20 \\ = & \frac{B C W P}{B A C}=\frac{12.32}{30.3}=0.406=41 \%\end{array}$


Percent Complete (on Forecast Total Cost EAC)

$\mathrm{EAC}=$

$$
\begin{aligned}
& =\frac{\mathrm{BAC}-\mathrm{BCWP}}{\mathrm{BCWP} / \mathrm{ACWP}} \\
& =\frac{30.3-12.32}{12.32 / 11.71}
\end{aligned}
$$

$$
=\frac{11.71}{28.83}=
$$

$=\underline{\mathrm{ACWP}}$

EAC

$\therefore$ Percent Complete on EAC $=\frac{11.71}{28.83}=0.406=41 \%$

\section{Report:}

The cost performance index CPI of 1.05 shows that US $\$ 1.05 \mathrm{~m}$ worth of planned work has been completed for each US\$1m actually spent to date.

Schedule Performance Index SPI shows that US $\$ 1.20 \mathrm{~m}$ worth of work has been accomplished for each US $\$ 1.0 \mathrm{~m}$ worth of scheduled work to date.

At month 10 the process plant work is 2 time periods ahead of schedule. It has cost saving of US $\$ 0.6 \mathrm{~m}$ from the budgeted performance of US $\$ 12.32 \mathrm{~m}$. Only $41 \%$ of the project budget cost has been spent. At this pace the project will be completed at US $\$ 28.83 \mathrm{~m}$ instead of budgeted installed cost of US $\$ 30.3$ Million (see Tables 4 and 5).

\section{Sustainability of Oil and Gas Projects}

Reports abound on the total neglect or inadequate maintenance of public infrastructure including refineries, oil pipelines, highways, railways, wharfs, etc. leading to their accelerated deterioration and early demise.

The Government special committee [17] on the Review of Petroleum Products, Supply and Distribution reported the inefficient management of turn-around maintenance (TAM) by Nigerian refineries and the vandalized and deteriorated state of oil pipelines leading to inefficient distribution of oil products. They recommended that NNPC should institute a policy of replacement of aged and obsolete equipment and a programmed and effective preventive maintenance and replacement culture.

Indeed, process plant is an operation project whose sustainability depends on the effective functioning of its process equipments/operations. Effective cost management and sustainability consideration starts at preinvestment stage through prudent application of tetrotechnology or cost-efficient equipment selection in project engineering and design parameters [4]. Process equipments have life expectancies and their replacements, refurbishments and maintenance should constitute the primary consideration at the project formulation $[3,15$, 16]. This is to say that costing of oil / gas projects should consider total cost- initial capital, replacement, operation and maintenance costs or whole- life-cycle cost, to reflect the operational nature of process project.

In this way its management becomes total cost management (TCM) that will ensure sustainability of the process plant $[3,18,19,20]$. Total cost management framework for oil/gas project is complex but I shall try to simplify its illustration, using cyclic maintenance cost schedule of hypothetical process plant costing US\$ 200 million at 1990 base year, interest rate 18\% inflation rate 5\% net discount rate NDR 12\% with uniform annual maintenance cost of US \$2 million (see table 6)

Here, the age or failure cohorts of all the process equipments; their associated installation bulk items and facilities are assessed, programmed and consolidated into a single chart which provides information on the physical life and cyclic maintenance for the plant as a whole [21, 22, 3]. In this way the periods of cluster of equipment/facility replacements and maintenance form the intermediate physical lives for Turnaround Maintenance which call for conscious budgetary/funding provisions for operational sustenance of the plant. This systematic maintenance approach provides maintenance baselines (cost benchmarks) for comparing and controlling the actual turnaround maintenance costs to ensure operational efficiency and sustainability [12, 23]. 
Table 6: Cyclic Maintenance Cost Schedule of a Hypothetical Process Plant Costing us $\$ 200 \mathrm{~m}$. At 1990 Base Year, Int. Rate 18\%, Infl. Rate 5\%, Ndr.12\%, Uniform Annual Maintenance Cost \$2m

\begin{tabular}{|c|c|c|c|c|c|c|c|c|c|c|c|}
\hline DATE (YEAR) & 199 & 2000 & 2010 & 2020 & 2030 & 2040 & 2050 & 2060 & 2070 & 2080 & 2090 \\
\hline ELEMENT (Life Span) & 0 & 10 & 20 & 30 & 40 & 50 & 60 & & 80 & 90 & 100 \\
\hline & Index 100 & 115 & 120 & 125 & 130 & 135 & 145 & & 165 & 170 & 175 \\
\hline EQUIPMENT. & $\begin{array}{l}\text { Maint. } \\
\text { Risk. } 5 \%\end{array}$ & & & & & & & & & & \\
\hline $\begin{array}{l}\text { Furnace } \\
\text { (90 YEARS) }\end{array}$ & $12 \mathrm{~m} \quad 6 \%$ & & & & & & & & & 21 & \\
\hline Package plants $(90$ years) & $22 \mathrm{~m} 11 \%$ & & & & & & & & & & \\
\hline Heat exchangers ( 90 years) & $14 \mathrm{~m} 7 \%$ & & & & & & & & & $\frac{39}{25}$ & \\
\hline Air Coolers (60 years) & $8 \mathrm{~m} \quad 4 \%$ & & & & & & 12 & & & & \\
\hline Compressors fans (20 years) & $\operatorname{lm} \quad .5 \%$ & & 1.3 & & 1.4 & & 1.5 & & 1.7 & & 1.8 \\
\hline Turbines ( 90 years) & $2 \%$ & & & & & & & & & & \\
\hline Pumps /Drivers (10 years) & $5 \%$ & 1.2 & 1.3 & 1.3 & 1.4 & 1.4 & 1.5 & & 1.6 & 1.8 & 1.8 \\
\hline Tanks (10years) & $3 \%$ & 3.6 & 3.8 & 3.9 & 8.1 & 8.4 & 4.6 & & 4.9 & 5.4 & 5.5 \\
\hline Vessels (35years) & & & & & 5.4 & & & & 6.5 & & \\
\hline Column Reactors (5 years) & $5 \%$ & 1.11 .2 & 1.21 .3 & 1.3 & 1.4 & 1.4 & 1.5 & 1.6 & 1.7 & 1.8 & 1.8 \\
\hline $\begin{array}{l}\text { Miscellaneous (5 years) } \\
\text { Equipment items }\end{array}$ & $\operatorname{lm} \quad .5 \%$ & 1.11 .2 & 1.21 .3 & 1.3 & 1.3 & 1.41 .4 & 1.5 & $\begin{array}{ll}1.6 & 1.6\end{array}$ & 1.71 .7 & 1.8 & 1.8 \\
\hline \multicolumn{12}{|l|}{ BULKITEMS } \\
\hline Structures (15 years) & $17 \%$ & & 21 & 22.3 & & 23.7 & 25.9 & & 28.6 & 30.3 & \\
\hline Piping \& valves (10 years) & $26 \mathrm{~m} \quad 13 \%$ & 15.6 & 16.3 & 17 & 17.7 & 18.4 & 19.7 & 21.1 & 22.5 & 23.2 & 23.8 \\
\hline Computer Control 20 years) & $5 \mathrm{~m} \quad 2.5 \%$ & & 5 & & 5.5 & & 6 & & 6.9 & & 7.4 \\
\hline Electrics $(20$ years) & $1.5 \%$ & & 3.8 & & 4.1 & & 4.6 & & 5.2 & & 5.5 \\
\hline Instrumentation (15 years) & $1 \%$ & & 2.5 & 2.6 & & 2.8 & 3 & & 3.3 & 3.6 & \\
\hline Insulation/Paints (15 years) & $3 \%$ & & 2.7 & 7.9 & & 8.4 & 9.1 & & 10 & 10.7 & \\
\hline Catalysts Chemicaloils (20 years) & $16 \mathrm{~m}$ & & 20.2 & & 21.8 & & 24.4 & & 27.7 & & 29.4 \\
\hline \multicolumn{12}{|l|}{ CIVIL WORKS } \\
\hline Piling (10 years) & $2 \%$ & 4.8 & 5 & 5.3 & 5.5 & 5.7 & 6.1 & 6.5 & 6.9 & 7.1 & 7.3 \\
\hline Foundations (10 years) & $4 \%$ & 9.6 & 10 & 10.5 & 10.9 & 11.3 & $\frac{1.2}{12.2}$ & 13 & 13.7 & 14 & 14.4 \\
\hline Buildings Transformer (15 years) & $6 \%$ & & 12.4 & 13.1 & & 14 & 15.2 & & 16.8 & 17.9 & \\
\hline Service roads (10 years) & $10 \mathrm{~m} \quad 5 \%$ & 6 & $\frac{.1 .7}{6.3}$ & 6.6 & 6.8 & 7.1 & -1.6 & 8.1 & 8.7 & 8.9 & 9.2 \\
\hline Lifecycle Cost Distribution & $200.00 \mathrm{~m}$ & 2.243 .2 & $45.7 \quad 75.6$ & $2.6 \quad 93.1$ & 82 & $51.7 \quad 51$ & $\begin{array}{lll}3 & 156.4 \\
\end{array}$ & 3.264 .9 & 62.1103 .6 & 204.5 & $3.6 \quad 95.3 \mathrm{~m}$ \\
\hline P.V.AnnualMaint. 2m @ $12 \%$ & 16.66 & & & & & & & & & & \\
\hline$D . F(a) 12 \%$ & - & .56 .32 & .05 .03 & .05 & $.01 \quad .011$ & .006 .003 & .001 .0011 & $\begin{array}{l}.0006 \\
.0003\end{array}$ & .0002 .0001 & .00006 .00003 & .00002 .0001 \\
\hline P.V. of Lifecycle Cost (LCC) & 35.41 & 1.2313 .8 & $.13 \quad 2.8$ & 2.8 & .08 & .35 & .003 .17 & .002 .02 & $.012 \quad .01$ & .0002 & $.00007 .001 \mathrm{~m}$ \\
\hline Total Lifecycle Cost (LCC) & $252.07 \mathrm{~m}$ & & & & & & & & & & \\
\hline
\end{tabular}

Sources: Author's Survey 2014

\section{Conclusion and Recommendation}

Sustainability of process projects goes beyond intraplant total cost management exemplified in the foregoing to the management of external factors which impact projects success, such as land, finite nature of crude, gas flaring, community/ youth restiveness and corporate social responsibility. Sustainability of process project correlates with serene plant environment. For instance, where as the certificate of occupancy (C of $\mathrm{O})$ provides satisfactory bankable documentation of land title it has not guaranteed the license to operate for companies who still have to deal with agitations. Hence companies must integrate community social development in a way that should not threaten oil business viability [2]. The strategy for a sustainable process operation must have an embedded win- win opportunity for companies, communities and governments, all working in close co-operation with each other.

For this to happen, apart from implementing efficient costing and lifecycle cost management requires:-

- that land acquisition process be re-streamlined/strengthened with fixed process times,

- that Governments strengthen regulation and enforcement of law and order and security,

- that Governments institute transparent/equitable sustainable community development (SCD) programmes,

- that plant operators promote "co-ownership-of-business-feel" in communities through employment/involvement of their youths in social development schemes to engender "co-progress" as sustained earning power reduces joblessness, agitation crime and resistance,

- sanction corruption in the process plants, and among corporate/community leaders,

- review penalty on gas flaring and compel plant owners to integrate pollution/effluent control systems in process designs,

- Quantity Surveyors should show more interest in cost management of process plant projects as is done by cost Engineers abroad to ensure sustenance of process business viability and by extension sustainable growth of the national economy.

\section{References}

[1]. NEEDS, National economic empowerment and development strategy, National Planning Commission, Abuja, 2004.

[2]. U.O. Ajator, Financial engineering and Project Risk Management Imperatives for Professional quantity Surveyors: Invited paper presented at the Annual Conference of NIQS Enugu State chapter held at the Sunshine Quest House 8-9 ${ }^{\text {th }}$ Aug. 2013.

[3]. U.O. Ajator, Total cost management of infrastructural projects (Ezu Books Ltd, Enugu-Nigeria, 2012).

[4]. U.O. Ajator, Development projects appraisal-practical feasibility/viability studies guide (Ezu Books Ltd. Nigeria, 2012)

[5]. U.O. Ajator, Project cost control fundamentals (Rojoint Communication Services, 2012).

[6]. OSHA Technical Manual, Petroleum refining processes http/www. oshagov/dts/osha/otm/otm'iv/otmiv2html,retrieved.2011

[7]. Joint Documentation Board, AACEI and RICS, Standard method of measurement for industrial engineering construction (Juniper Press Limited, Croydon surrey, Great Britain, 1984). 
[8]. British Gas, Method of measurement for onshore pipeline works including installation (British Gas PLC, 1992).

[9]. M.C. Oforeh, Cost management of heavy capital projects, Vol. 1 (Cosine (Nig) Ltd, 2006).

[10]. AACEI, Guidelines and terms of references for preparation of project cost estimate in cost engineering, Notebook, AACEI. USA, 1995.

[11]. U.O. Ajator, Project controls in process plant, heavy engineering, oil and gas projects, Institute for Development Studies, IDS University of Nigeria Enugu-Campus, Enugu, 2012.

[12]. U.O. Ajator, Fundamentals of cost engineering, cost management and value management, Research Documentation Book Series (Luvaj Technologies Nigeria. 2010)

[13]. S.O. Ekpo, Project controls, presented paper at the NIQS National Conference held at UNILAG Conference Centre, 13-15 October, Lagos, 1993.

[14]. L.R. Dysert, Estimating, in skill and knowledge of cost engineering, $5^{\text {th }}$ Edition (Amos Scott Edit, AACE/USA, 2007).

[15]. U.O. Ajator, Construction and facility cost benchmarking, Cost Research and Management (CRAM) Centre-sponsored Research Documentation series.2011

[16]. U.O. Ajator, Heavy engineering construction estimating and measurement, Lecture Mimeograph QS Dept NAU, Awka. 2011

[17]. Report of Govt. Special Committee, Review of petroleum products supply and distribution, Federal Republic of Nigeria Oct. 2000

[18]. AACEI, Process plant capital cost estimating -A Science Rather than an Art in Cost Engineering Note Book, AACEI, USA, 1995.

[19]. AACEI Technical Board, Total cost management (TCM) framework: A Process for Applying the Skills and Knowledge of Cost Engineering, PDF Files, AACE International $50^{\text {th }}$ Anniversary Meeting Website Publication, 2006. www/org.Las-Vegas.

[20]. U.O. Ajator, and S.O. Onyeador, Total cost management framework for sustainability of physical facilities of federal universities, Journal of Environment and Social Harmony, Faculty of Environmental Sciences Enugu State University of Science and Technology, ESUT, 12(1), March, 2009, 121-143.

[21]. A.S. Cowell, Aging an aspect of long-term maintenance (IOB Maintenance Information Services, 1978).

[22]. U.O. Ajator, Condition independent life expectancy/cyclic maintenance schedule, University World Journal, 1(2), Sept.2001, 101119, Enugu

[23]. U.O. Ajator, Sustainable development - an imperative for Nigerian construction practice, in the quantity surveyor, Journal of Nigerian Institute of Quantity Surveyors (NIQS), 26, Jan/March, 1999, 15-20. 